\title{
Xenopus laevis and emerging amphibian pathogens in Chile
}

Claudio Soto-Azat ${ }^{1}$, Alexandra Peñafiel-Ricaurte ${ }^{1}$, Stephen J. Price ${ }^{2,4}$, Nicole SallaberryPincheira ${ }^{1}$, María P. García ${ }^{1,3}$, Mario Alvarado ${ }^{1}$ \& Andrew A. Cunningham ${ }^{4}$.

${ }^{1}$ Centro de Investigación para la Sustentabilidad, Facultad de Ecología y Recursos Naturales, Universidad Andres Bello, Republica 440, Santiago, Chile.

${ }^{2}$ UCL Genetics Institute, Gower Street, London WC1E 6BT, United Kingdom.

${ }^{3}$ Molecular Virology Laboratory, Fundación Ciencia \& Vida, Av. Zañartu 1482, Ñuñoa, Chile.

${ }^{4}$ Institute of Zoology, Zoological Society of London, Regent's Park, London NW1 4RY, United Kingdom.

Running Head: Ranavirus and Batrachochytrium dendrobatidis in Chile

Key Words: Ranavirus, Frog virus 3, Batrachochytrium dendrobatidis, Xenopus laevis, reservoir, Calyptocephalella gayi, Chile.

\section{Corresponding author:}

Claudio Soto Azat

Centro de Investigación para la Sustentabilidad, Facultad de Ecología y Recursos Naturales, Universidad Andres Bello.

Republica 440, Santiago, Chile.

Phone: +56968988968

Fax: +56226618661

Email: csoto@unab.cl 


\section{ABSTRACT}

Amphibians face an extinction crisis with no precedent. Two emerging infectious diseases: ranaviral disease caused by viruses within the genus Ranavirus and chytridiomycosis due to Batrachochytrium dendrobatidis (Bd), have been linked with

amphibian mass mortalities and population declines in many regions of the globe. The African clawed frog (Xenopus laevis) has been indicated as a vector for the spread of these pathogens. Since the 1970s, this species has been invasive in central Chile. We collected X. laevis and dead native amphibians in Chile between 2011 and 2013. We conducted post-mortem examinations and molecular tests for Ranavirus and Bd. Eight of 187 individuals (4.3\%) tested positive for Ranavirus: seven X. laevis and a giant Chilean frog (Calyptocephallela gayi). All positive cases were from the original area of $X$. laevis invasion. Bd was found to be more prevalent (14.4\%) and widespread than Ranavirus and all X. laevis Bd-positive animals presented low to moderate levels of infection. Sequencing of a partial Ranavirus gene revealed 100\% sequence identity with Frog Virus 3. This is the first report of Ranavirus in Chile and these preliminary results are consistent with a role for $X$. laevis as an infection reservoir for both Ranavirus and Bd.

\section{INTRODUCTION AND PURPOSE}

Amphibians are considered the most imperilled class of vertebrates (Stuart et al. 2004). In recent years, evidence for the critical involvement of emerging infectious diseases in the decline of amphibian populations has grown and become more convincing, especially in the case of chytridiomycosis caused by Batrachochytrium dendrobatidis (Bd; Berger et al. 1998). Lethal outbreaks caused by Ranavirus have been reported in many parts of the world (Cunningham et al. 1996; Jancovich et al. 1997; Green et al. 2002; Greer et al. 2005; Fox et al. 2006; Muths et al. 2006; Balseiro et al. , 2010; Une et al. 2009; Kik et al. 2011; Stöhr et al. 2013), long-term population declines confirmed for the common frog (Rana temporaria) in the United Kingdom (Teacher et al. 2010) and severe amphibian community level impacts described in 
Spain (Price et al. 2014). Chytridiomycosis has been implicated in the extinction of several amphibian species from Australia, Costa Rica and Chile (Daszak et al. 1999; Pounds et al. 2006; Schloegel et al. 2006; Soto-Azat et al. 2013a, b).

Ranaviruses cause systemic haemorrhagic disease in amphibians, fish and reptiles (Hyatt et al. 2000; Miller et al. 2011). The pathogen infects multiple amphibian hosts, including tadpoles and adults, and may persist in aquatic and terrestrial environments through amphibian, fish or reptile reservoirs (Hyatt et al. 2000). The chytrid fungus Bd is a highly-pathogenic and virulent pathogen, which appears to be capable of infecting the entire class Amphibia (Berger et al. 1998; Gower et al. 2013; Olson and Ronnenberg 2014). In susceptible adult amphibians, Bd colonizes the skin, disrupting the integrity of the epidermis, with subsequent electrolyte depletion and osmotic imbalance leading to death (Voyles et al. 2009). Tadpoles and resistant species or populations may act as reservoirs of infection (Berger et al. 1998; Daszak et al. 1999; Schloegel et al. 2006). The type species of Ranavirus, Frog Virus 3 (FV3) and a hypervirulent genotype of $B d$, termed the global pandemic lineage (BdGPL), are known to be globally widespread, while other species of Ranavirus and other lineages of Bd appear to be more restricted in distribution (Farrer et al. 2013; Duffus et al. 2015). Although poorly studied in South America, evidence of Ranavirus has been obtained from free-ranging amphibians in Venezuela, Argentina and Peru (Zupanovic et al. 1998; Fox et al. 2006; Warne et al. 2016) and from farmed North American bullfrogs (Lithobates catesbeianus) from Uruguay and Brazil (Galli et al. 2006; Mazzoni et al. 2009). Better studied, Bd appears to be widely distributed in South America (Mazzoni et al. 2003; Hanselmann et al. 2004; Pounds et al. 2006; Schloegel et al. 2010, 2012; Solís et al. 2010, 2015; Bourke et al. 2011; SotoAzat et al. 2013a; Olson and Ronnenberg 2014; James et al. 2015; Warne et al. 2016).

Chilean batrachofauna consist of 63 anuran species, characterized by a high degree of endemism (72\%, Soto-Azat et al. 2015). Since its introduction in the 1970s, the African clawed frog (Xenopus laevis) has become established throughout much of central Chile (Lobos and Jaksic 2005) and, recently, Bd infection has been described in 
this species in Chile (Solís et al. 2010). Whilst X. laevis is generally resistant to developing ranavirosis or chytridiomycosis, it is tolerant to infection with both causative pathogens (Robert et al. 2007; Ramsey et al. 2010). This species is thus theoretically capable of disseminating both Ranavirus and Bd to new geographical areas and amphibian populations, where it might also serve as a reservoir of infection (Hanselmann et al. 2004; Fisher and Garner 2007; Schloegel et al. 2010; Greenspan et al. 2012). Here, we investigated the Ranavirus and Bd carrier status of $X$. laevis in Chile and looked for evidence of infection in sympatric native species.

\section{MATERIAL AND METHODS}

Study area. Amphibians were collected from seven sites in central Chile from 2011 to 2013 (see Fig. 1), all within or near the invasive range of $X$. laevis. These included natural environments as well as those transformed through agriculture. Only adult frogs were collected and each site was visited once during the amphibian breeding season (November to March). We also responded to reports of mortality events by visiting sites as soon as possible to collect fresh carcasses.

Sampling. Our opportunistic sampling consisted of animals that had died in the wild as well as euthanized animals (in this case only $X$. laevis). Amphibian carcasses found recently dead were collected following mortality events. Carcass numbers ranged from single animals to 79. We also received the internal organs of eight individuals harvested for human consumption from a commercial giant Chilean frog (Calyptocephallela gayi) aquaculture facility. In addition, X. laevis was live captured using funnel traps set up at the margin of water bodies. This species is considered harmful under the Chilean Wildlife Act (Law № 19473), and can be captured all year round without limits on the number and use of captured individuals. Traps were baited with chicken heart and checked twice daily. Captured X. laevis were then euthanized individually via immersion in a buffered solution of $10 \mathrm{~g} / \mathrm{L}$ tricaine methanesulfonate (Dolical 80\%, Centrovet), which has been demonstrated to be safe for Bd studies based on molecular detection (Webb et al. 2005). Immediately after 
collection of dead amphibians or euthanasia of $X$. laevis, each individual was skin swabbed for Bd detection following Hyatt et al. (2007), examined for gross lesions and dissected following standard necropsy procedures to obtain liver, kidney and spleen for molecular tests for Ranavirus. New sterile disposable scalpels were used to avoid cross-contamination. Tissues were collected separately in $2 \mathrm{ml}$ sterile Eppendorf tubes containing 95\% sterile ethanol. Each individual was handled using a new pair of disposable gloves. Furthermore, in order to minimize any contamination of samples or the spread of pathogens within or between study sites by researchers, equipment or materials, a strict field sampling and disinfection protocol was followed, with reference to Phillot et al. (2010).

PCR assay for Bd. Tips of skin swabs were each added to $1.5 \mathrm{ml}$ Eppendorf tubes containing $60 \mathrm{ml}$ of PrepMan Ultra (Applied Biosystems) and between 30 to $40 \mathrm{mg}$ of Zirconium/silica beads of $0.5 \mathrm{~mm}$ diameter (Biospec Products). For each sample, DNA was extracted following the protocol of Boyle et al. (2004). Extracted DNA was diluted (1:10) in double-distilled water and analysed using a quantitative real-time PCR Taqman assay (qPCR) with primers specific for the ITS-1/5.8S ribosomal DNA region of Bd. In addition, bovine serum albumin (BSA) was included in the Taqman mastermix to minimise PCR inhibition (Garland et al. 2010). Each assay was run in 25 $\mu \mathrm{l}$ PCR reactions and thermocycling conditions were $2 \mathrm{~min}$ at $50^{\circ} \mathrm{C}, 10 \mathrm{~min}$ at $95^{\circ} \mathrm{C}$, followed by $15 \mathrm{~s}$ at $95^{\circ} \mathrm{C}$ and $1 \mathrm{~min}$ at $60^{\circ} \mathrm{C}$ for 50 cycles. For each sample, diagnostic assays were performed in duplicate, and standards of known zoospore concentration were included within each PCR plate, as were negative controls. In order to quantify the Bd genome equivalents (GE) in each well, we multiplied the qPCR result by 120 , as described by Hudson et al. (2016). A result was considered positive when: (1) amplification (i.e. a clearly sigmoid curve) occurred in both replicate PCR assays, (2) values higher than $0.1 \mathrm{GE}$ were obtained from both replicated reactions, and (3) a sample's mean GE value was greater than its standard deviation.

\section{PCR assay, DNA sequencing and DNA sequence analysis for Ranavirus. Small} pieces (0.01-0.05 g) of sampled visceral organs of the same animal were pooled and 
analysed. Samples were homogenised together in tubes containing $250 \mu \mathrm{l}$ of lysis buffer and then incubated at 56을 overnight. DNA was extracted using a Wizard Genomic DNA Purification Kit (Promega) following the manufacturer's instructions. MCP-F and MCP-R primers were used to amplify a 530 base pair fragment of the Ranavirus major capsid protein (MCP) in $25 \mu \mathrm{l}$ PCR reactions, following the protocol of Mao et al. (1997), modified by Greer et al. (2005). Thermocycling conditions were $94^{\circ} \mathrm{C} 5 \mathrm{~min}, 94^{\circ} \mathrm{C} 30 \mathrm{~s}, 5^{\circ} \mathrm{C} 30 \mathrm{~s}$ and $60^{\circ} \mathrm{C} 30 \mathrm{~s}$, cycled 35 times, followed by an extension of $72^{\circ} \mathrm{C} 2 \mathrm{~min}$. All PCR assays were run in duplicate with a positive (previously obtained FV3 DNA) and a negative (water) control tested alongside the unknown samples. PCR products were stained with Sybr Safe (Invitrogen) and visualized following electrophoresis on $2 \%$ agarose gels. Samples were considered positive when bands matched the size of the positive control bands. The PCR products of positive samples were submitted (Beckman Coulter Genomics, UK) for Sanger sequencing of both DNA strands. Sequences generated from the reverse primer were reverse-complemented prior to alignment of all sequences using MEGA6 (Tamura et al. 2013). Sequences were trimmed to remove low quality base calls and checked by eye for consistency between complementary DNA strands. We then compared our processed sequences to other publicly available Ranavirus sequences in the National Center for Biotechnology Information (NCBI) nucleotide database using BLAST.

\section{RESULTS}

A total of 187 individuals of four amphibian species were investigated for evidence of Ranavirus and Bd infection. Characteristics and results of molecular tests for each study site are shown in Table 1. Of the amphibians examined, 96 X. laevis were captured with the use of baited funnel traps, $79 \mathrm{X}$. laevis and four individuals of native species were collected dead from mortality events, and the tissues of eight $C$. gayi were obtained from an aquaculture facility. Overall, $4.3 \%$ and $14.4 \%$ of animals tested were positive for Ranavirus and Bd, respectively. All Ranavirus-positive amphibians (7 X. laevis, 1 C. gayi), were from two sites within the Metropolitan Region near to Santiago, the original site of $X$. laevis introduction in Chile (Fig 1.). Bd was 
found to be more widespread amongst sites and species, with all but one site with $X$. laevis being positive (Fig. 1).

All Ranavirus-positive X. laevis were apparently healthy individuals; they were live captured and did not present any lesions consistent with ranavirosis. In contrast, the other Ranavirus-positive animal, a $2.2 \mathrm{~kg}$ female C. gayi $(22.4 \mathrm{~cm}$ snout-ventlength, and estimated to be more than 15 years old based on size), was found dead by a member of the public and then collected for investigation. The animal had been stored frozen until the post-mortem examination, where it presented with abundant clear serosanguinous subcutaneous fluid. Within the intracoelomic cavity, a large amount of a dark serosanguinous fluid was found. Internal organs were moderately oedematous. The internal surface of the left lung was extensively haemorrhagic. No other macroscopic changes were noticeable. Histopathological analyses were not informative as autolysis of organs was advanced. None of the other amphibians studied from mortality events, comprising two four-eyed toads (Pleurodema thaul), a Bullock's toad (Telmatobufo bullocki) and 79 X. laevis, gave Ranavirus-positive results. Most (24 of 27) Bd-positive cases were categorized as low to moderate intensity infections by qPCR (30-9,816 GE), including all Bd-positive X. laevis. Three C. gayi, however, had severe intensities of infection $(<25,368 \mathrm{GE}$ ) indicative of disease. However, no signs or lesions attributable to chytridiomycosis were observed in any of the surveyed animals. All C. gayi from one site (Longaví) were infected with Bd (and negative to Ranavirus). The individual of $C$. gayi found dead in Talagante, co-habiting with X. laevis, resulted positive for Ranavirus, but negative for Bd. Three animals with co-infections were detected, all of which were X. laevis: two from Maipú and one from Talagante (Fig. 1, Table 1).

Nucleotide sequences of Ranavirus PCR products were obtained from four positive frogs ( 3 X. laevis, 1 C. gayi). All sequences were $100 \%$ identical to each other and to FV3 (NCBI ref. AY548484) and had 99\% similarity with Rana grylio Iridovirus (JQ654586), Rana catesbiana virus (AB474588), and Common midwife toad Ranavirus (KP056312); 98\% similarity with Bohle Iridovirus (AY187046) and 95\% similarity 
with Ambystoma tigrinum virus (KR075877). The sequences showed no significant similarity to any non-Ranavirus sequences in the NCBI nucleotide database, confirming the specificity of the PCR assay.

\section{DISCUSSION}

We found evidence of infection of the emerging amphibian pathogens, Ranavirus and $\mathrm{Bd}$, in the invasive X. laevis and in native species in central Chile. Although clinical chytridiomycosis was not detected, a Ranavirus-positive individual of $C$. gayi which had been found dead had internal lesions consistent with ranavirosis. Unfortunately, the condition of the tissues (frozen/thawed and autolysed) precluded histopathological examination, so this presumptive cause of death could not be confirmed. Of the animals tested, $4.3 \%$ were positive for Ranavirus. Our sequence analyses of the MCP region of Ranavirus are a robust confirmation of our initial PCR findings, and follow OIE recommendations (OIE 2015) to support imperfect molecular methods with corroborative evidence, especially when assessing Ranavirus occurrence in a previously unstudied region. In addition, these sequence data serve as initial genetic characterisation of the Ranavirus found in central Chile, which appears to be closely related to the type Ranavirus, FV3. Our findings further extend the patchy, global distribution of this virus type (Duffus et al. 2015). Isolation and whole genome sequencing of local isolates, as well as the development of primers targeting hypervariable DNA regions of Ranavirus to distinguish between different strains, will undoubtedly help to further characterize ranaviruses in Chile and may provide information on their evolutionary history and source (endemic vs introduced) through comparative phylogeny (Holopainen et al. 2009; Jancovich et al. 2015).

To the best of our knowledge, this is the first evidence of Ranavirus in Chile. We detected Ranavirus infection at only two of our study sites, but sample sizes were generally small, limiting our ability to detect the pathogen if at a low infection prevalence. This is seen in the large confidence intervals obtained for those sites and species underrepresented (Tables 1 and 2). It is possible, therefore, that Ranavirus 
infection is more widespread than our findings suggest. Increasing the number and range of study sites, the numbers of animals sampled per site and the number of species sampled may improve detection and extend the current known distribution of Ranavirus in Chile.

In contrast to our Ranavirus results, at least one Bd-positive animal was detected from five of our seven study sites. All sites with $X$. laevis presence except one, resulted positive for Bd. In the C. gayi aquaculture facility (area still not invaded by $X$. laevis, but expected to occur within the next years) all studied animals (eight) resulted positive for Bd. This pathogen has been reported from X. laevis in central Chile (Solís et al. 2010) and from a range of native species across a latitudinal extension of $\sim 3,000$ km (Bourke et al. 2011; Soto-Azat et al. 2013a; Solís 2015). In the current study, we found the prevalence of $\mathrm{Bd}$ infection to range from zero to $41.7 \%$ in the $X$. laevis populations sampled, with all individuals showing low to moderate levels of infection, suggestive of a Bd reservoir function of this species when co-habiting with other susceptible amphibian species. Also, we found all eight of the farmed C. gayi tested to be Bd-positive, even with molecular evidence supporting the occurrence of chytridiomycosis, indicating endemicity of infection on the frog farm in question and possibly in other amphibian aquaculture in Chile, as has been reported for frog aquaculture elsewhere in South America (Mazzoni et al. 2003; Schloegel et al. 2012).

Bd was detected in one of two dead $P$. thaul collected from the El Peral lagoon in April 2012. In contrast, no evidence of Bd was obtained from the 79 dead X. laevis collected from a mass mortality event at the same site in 2013. On 27 May 2013 $\sim 2000$ X. laevis left El Peral lagoon coincident with a period of heavy rain. On the following day, many hundreds of these frogs were found dead in the surrounding area, but only fresh carcasses or moribund (euthanized) animals were sampled. This mass movement of $X$. laevis appears to be associated with the colonization of new environments that may occur during heavy rainfall (Tinsley et al. 1996). X. laevis, originally from Africa, was introduced to Chile in the 1970s, with the initial site of introduction being the international airport near Santiago. Solís et al. (2010) and Soto- 
Azat et al. (2013a) speculated that Bd might have been co-introduced to Chile with $X$. laevis. Non-native host introductions have been identified as a predictor of $\mathrm{Bd}$ occurrence at the global level (Liu et al. 2013) and urban development has been positively correlated with the presence of both Bd (Murray et al. 2011; Rhor et al. 2011) and Ranavirus (North et al. 2015; St-Amour et al. 2008). In Chile, the highest occurrence of Bd has been found in the central region between Santiago and Concepción, an area containing $>70 \%$ of the country's human population (Soto-Azat et al. 2013a; James et al. 2015). In addition, Robert et al. (2007) found that a significant fraction of $X$. laevis adults raised in captivity in different places in the United States carried covert FV3 infections, which may have contributed to the spread of Ranavirus in the United States. An apparent restricted distribution of Ranavirus, associated with the occurrence of invasive $X$. laevis in central Chile, compared to the widespread distribution of $\mathrm{Bd}$ in the country, maybe the result of different introductions processes or mechanisms of spread (for instance, better habitat suitability for Bd). However, whether either Bd or Ranavirus are recent introductions to Chile via Xenopus requires further investigation, including comparative pathogen genomics. In effect, this study and preliminary Bd genotype data provide evidence on the occurrence of FV3 and BdGPL in the country. Efforts to isolate endemic strains of both pathogens (if any) have not been successful so far, all this giving support to a role of $X$. laevis in pathogen introduction, maintenance and spread.

Amphibian species show differential susceptibility to Bd and Ranavirus depending of life-stage (Fisher et al. 2009; Miller et al. 2011; De Jesús Andino et al. 2012). Since samples obtained in this study were opportunistic, and included only four species (one potentially a competent reservoir), and considering that sites were visited once and only adult amphibians were studied, our results may underestimate the extent of occurrence of these pathogens in Chile, a reason to extend future studies to include sampling of tadpoles, as well as samples of additional sites and species. This study also is a good example of using wildlife mortalities and invasive species as a convenient source of information to study wildlife diseases of conservation concern (Sleeman et al. 2012). 


\section{CONCLUSION}

Emerging infectious diseases have been increasingly recognized as a threat to biodiversity, especially as wildlife populations become more fragmented and are increasingly living in sub-optimal environments (Smith et al. 2009). For example, Soto-Azat et al. (2013a) showed that Bd is likely driving precipitous declines of Darwin's frogs (Rhinoderma spp.) in Chile. Currently, 47\% of Chilean amphibian species are threatened with extinction and 37\% have undergone population declines (Soto-Azat et al. 2015). Among these, the once abundant C. gayi is currently listed as Vulnerable by the IUCN and its populations have markedly declined over the last two decades, due to over-exploitation for food and agricultural development (Veloso et al. 2010). In addition, chytridiomycosis (Soto-Azat et al. 2013a) and Ranavirus (this report) have been identified as potential additional threats to this endemic species (Soto-Azat et al. 2015). Whether Ranavirus and/or Bd are negatively impacting this and other native amphibians in Chile should be further investigated. All Ranavirus positive cases were restricted to the invasive distribution of $X$. laevis and all Bdpositive $X$. laevis showed low to moderate levels of infection. Our results are consistent with a reservoir role of $X$. laevis for Ranavirus and $\mathrm{Bd}$ in Chile, however additional field and laboratory analyses are required to verify this.

\section{REFERENCES}

Balseiro A, Dalton KP, Del Cerro A, Márquez I, Parra F, Prieto JM, Casais R (2010) Outbreak of common midwife toad virus in alpine newts (Mesotriton alpestris cyreni) and common midwife toads (Alytes obstetricans) in Northern Spain: A comparative pathological study of an emerging ranavirus. The Veterinary Journal 186:256-258

Berger L, Speare R, Daszak P, Green DE, Cunningham AA, Goggin CL, Slocombe R, Ragan MA, Hyatt AD, McDonald KR, Hines HB, Lips KR, Marantelli G, Parkes H (1998) Chytridiomycosis causes amphibian mortality associated with population 
declines in the rain forests of Australia and central America. Proceedings of the National Academy of Sciences of the United States of America 95:9031-9036

Bourke J, Ohst T, Graser Y, Bohme W, Plotner J (2011) New records of Batrachochytrium dendrobatidis in Chilean frogs. Diseases of Aquatic Organisms 95:259-261

Boyle DG, Boyle DB, Olsen V, Morgan JAT, Hyatt AD (2004) Rapid quantitative detection of chytridiomycosis (Batrachochytrium dendrobatidis) in amphibian samples using real-time Taqman PCR assay. Diseases of Aquatic Organisms 60:141-148

Cunningham AA, Langton TES, Bennett PM, Lewin JF, Drury SEN, Gough RE, MacGregor SK (1996) Pathological and microbiological findings from incidents of unusual mortality of the common frog (Rana temporaria). Philosophical Transactions of the Royal Society of London Series B-Biological Sciences 351:1539-1557

Daszak P, Berger L, Cunningham AA, Hyatt AD, Green DE, Speare R (1999) Emerging infectious diseases and amphibian population declines. Emerging Infectious Diseases 5:735-748

De Jesús Andino F, Chen G, Li Z, Grayfer L, Robert J (2012) Susceptibility of Xenopus laevis tadpoles to infection by the ranavirus Frog-Virus 3 correlates with a reduced and delayed innate immune response in comparison with adult frogs. Virology 432:435-443

Duffus ALJ, Waltzek TB, Stöhr AC, Allender MC, Gotesman M, Whittington RJ, Hick P, Hines MK, Marschang RE (2015) Distribution and host range of ranaviruses. In: Ranaviruses: lethal pathogens of ectothermic vertebrates, Gray MJ, Chinchar VG (editors), New York, Springer, pp 71-104

Farrer RA, Weinert LA, Bielby J, Garner TWJ, Balloux F, Clare F, Bosch J, Cunningham AA, Weldon C, du Preez LH, Anderson L, Pond SLK, Shahar-Golan R, Henk DA, Fisher MC (2011) Multiple emergences of genetically diverse amphibian-infecting chytrids include a globalized hypervirulent recombinant lineage. Proceedings of the National Academy of Sciences of the United States of America 108:1873218736

Fisher MC, Garner TWJ (2007) The relationship between the emergence of Batrachochytrium dendrobatidis, the international trade in amphibians and introduced amphibian species. Fungal Biology Reviews 21: 2-9

Fisher MC, Garner TWJ, Walker SF (2009) Global emergence of Batrachochytrium dendrobatidis and amphibian chytridiomycosis in space, time, and host. Annual Review of Microbiology 63:291-310

Fox SF, Greer AL, Torres-Cervantes R, Collins JP (2006) First case of ranavirusassociated morbidity and mortality in natural populations of the South American frog Atelognathus patagonicus. Diseases of Aquatic Organisms 72:87-92 
Galli L, Pereira A, Marquez A, Mazzoni R (2006) Ranavirus detection by PCR in cultured tadpoles (Rana catesbeiana Shaw 1802) from South America. Aquaculture 257:78-82

Garland S, Baker A, Phillott AD, Skerratt LF (2010) BSA reduces inhibition in a TaqMan assay for the detection of Batrachochytrium dendrobatidis. Diseases of Aquatic Organisms 92:113-116

Gower DJ, Doherty-Bone T, Loader SP, Wilkinson M, Kouete MT, Tapley B, Orton F, Daniel OZ, Wynne F, Flach E, Müller H, Menegon M, Stephen I, Browne RK, Fisher MC, Cunningham AA, Garner TWJ (2013) EcoHealth 10:173-183

Green DE, Converse KA, Schrader AK (2002) Epizootiology of sixty-four amphibian morbidity and mortality events in the USA, 1996-2001. Annals of the New York Academy of Sciences 969:323-339

Greenspan SE, Calhoun AJK, Longcore JE, Levy MG (2012) Transmission of Batrachochytrium dendrobatidis to wood frogs (Lithobates sylvaticus) via a bullfrog (L. catesbeianus) vector. Journal of Wildlife Diseases 48:575-582

Greer AL, Berrill M, Wilson PJ (2005) Five amphibian mortality events associated with ranavirus infection in south central Ontario, Canada. Diseases of Aquatic Organisms 67:9-14

Hanselmann R, Rodriguez A, Lampo M, Fajardo-Ramos L, Aguirre AA, Kilpatrick AM, Rodriguez JP, Daszak P (2004) Presence of an emerging pathogen of amphibians in introduced bullfrogs Rana catesbeiana in Venezuela. Biological Conservation 120:115-119

Holopainen R, Ohlemeyer S, Schütze H, Bergmann SM, Tapiovaara H (2009) Ranavirus phylogeny and differentiation based on major capsid protein, DNA polymerase and neurofilament triplet H1-like protein genes. Diseases of Aquatic Organisms 8:81-91

Hudson MA, Young RP, Lopez J, Martin L, Fenton C, McCrea R, Griffiths RA, Adams S-L, Gray G, Garcia G, Cunningham AA (2016) In-situ itraconazole treatment improves survival rate during an amphibian chytridiomycosis epidemic. Biological Conservation 195:37-45

Hyatt AD, Gould AR, Zupanovic Z, Cunningham AA, Hengstberger S, Whittington RJ, Kattenbelt J, Coupar BE (2000) Comparative studies of piscine and amphibian iridoviruses. Archives of Virology 145:301-331

Hyatt AD, Boyle DG, Olsen V, Boyle DB, Berger L, Obendorf D, Dalton A, Kriger K, Hero M, Hines H, Phillott R, Campbell R, Marantelli G, Gleason F, Colling A (2007) Diagnostic assays and sampling protocols for the detection of Batrachochytrium dendrobatidis. Diseases of Aquatic Organisms 73:175-192

James TY, Toledo LF, Rödder D, Leite DS, Belasen A, Betancourt-Román CM, Jenkinson TS, Soto-Azat C, Lambertini C, Longo AV, Ruggeri J, Collins JP, Burrowes P, Lips KR, Zamudio KR, Longcore JE (2015) Disentangling host, pathogen, and 
environmental determinants of a recently emerged wildlife disease: lessons from the first 15 years of amphibian chytridiomycosis research. Ecology and Evolution 5:4079-4097

Jancovich JK, Davidson EW, Morado JF, Jacobs BL, Collins JP (1997) Isolation of a lethal virus from the endangered tiger salamander Ambystoma tigrinum stebbinsi.

Diseases of Aquatic Organisms 31:161-167

Jancovich JK, Steckler NK, Waltzek TB (2015) Ranavirus taxonomy and phylogeny In: Ranaviruses: lethal pathogens of ectothermic vertebrates, Gray MJ, Chinchar VG (editors), New York, Springer, pp 59-70

Kik M, Martel A, Spitzen-van der Sluijs A, Pasmans F, Wohlsein P, Gröne A, Rijks JM (2011) Ranavirus-associated mass mortality in wild amphibians, The Netherlands, 2010: A first report. Veterinary Journal 190:284-286

Liu X, Rohr JR, Li YM (2013) Climate, vegetation, introduced hosts and trade shape a global wildlife pandemic. Philosophical Transactions of the Royal Society of London Series B-Biological Sciences 280:20122506

Lobos G, Jaksic FM (2005) The ongoing invasion of African clawed frogs (Xenopus leavis) in Chile: causes of concern. Biodiversity and Conservation 14:429-439

Mao J, Hedrick RP, Chinchar VG (1997) Molecular characterization, sequence analysis, and taxonomic position of newly isolated fish iridoviruses. Virology 229:212-220

Mazzoni R, de Mesquita AJ, Fleury LF, de Brito WM, Nunes IA, Robert J, Morales H, Coelho AS, Barthasson DL, Galli L, Catroxo MH (2009) Mass mortality associated with a Frog Virus 3-like ranavirus infection in farmed tadpoles Rana catesbeiana from Brazil. Diseases of Aquatic Organisms 86:181-191

Mazzoni, R., Cunningham, A. A., Daszak, P., Apolo, A., Perdomo, E., and Speranza, G. (2003) Emerging pathogen of wild amphibians in frogs (Rana catesbeiana) farmed for international trade. Emerging Infectious Diseases 9:995-998

Miller DL, Gray MJ, Storfer A (2011) Ecopathology of ranaviruses infecting amphibians. Viruses 3:2351-2373

Murray KA, Retallick RWR, Puschendorf R, Skerratt LF, Rosauer D, McCallum HI, Berger L, Speare R, VanDerWal J (2011) Assessing spatial patterns of disease risk to biodiversity: implications for the management of the amphibian pathogen, Batrachochytrium dendrobatidis. Journal of Applied Ecology 4:163-173

Muths E, Gallant AL, Campbell EHC, Battaglin WA, Green DE, Staiger JS, Walls SC, Gunzburger MS, Kearney RF (2006) The Amphibian Research and Monitoring Initiative (ARMI): 5-year report. US Geological Survey Scientific Investigations Report 2006-5224

North AC, Hodgson DJ, Price SJ, Griffiths AGF (2015) Anthropogenic and ecological drivers of amphibian disease (ranavirosis). PLoS ONE 10:e0127037 
OIE (World Organisation for Animal Health) (2015) Manual of diagnostic tests for aquatic animals 2015. Available: www.oie.int/international-standardsetting/aquatic-manual/access-online/ [accessed March 14, 2016]

Olson DH, Ronnenberg KL (2014) Global Bd mapping project: 2014 update. FrogLog 22:17-21

Price S, Garner TWJ, Nichols RA, Balloux F, Ayres C, Mora-Cabello de Alba A, Bosch J (2014) Collapse of amphibian communities due to and introduced Ranavirus. Current Biology 24:2586-2591

Phillot AD, Speare R, Hines HB, Skerrat LF, Meyer E, McDonald KR, Cashins SD, Mendez D, Berger L (2010) Minimising exposure of amphibians to pathogens during field studies. Diseases of Aquatic Organisms 92:175-185

Pounds AJ, Bustamante MR, Coloma LA, Consuegra JA, Fogden MPL, Foster PN, la Marca E, Masters KL, Merino-Viteri A, Puschendorf R, Ron SR, Sanchez-Azofeifa GA, Still CJ, Young BE (2006) Widespread amphibian extinctions from epidemic disease driven by global warming. Nature 439:161-167

Ramsey JP, Reinert LK, Harper LK, Woodhams DC, Rollins-Smith LA (2010) Immune defenses against Batrachochytrium dendrobatidis, a fungus linked to global amphibian declines, in the South African clawed frog, Xenopus laevis. Infection and Immunity 78:3981-3992

Robert J, Abramowitz L, Gantress J, Morales HD (2007) Xenopus laevis: a possible vector of ranavirus infection? Journal of Wildlife Diseases 43:645-652

Rohr JR, Halstead NT, Raffel TR (2011) Modelling the future distribution of the amphibian chytrid fungus: the influence of climate and human-associated factors. Journal of Applied Ecology 48:174-176

Schloegel LM, Hero JM, Berger L, Speare R, McDonald K, Daszak P (2006) The decline of the sharp-snouted day frog (Taudactylus acutirostris): the first documented case of extinction by infection in a free-ranging wildlife species? EcoHealth 3:3540

Schloegel LM, Ferreira CM, James TY, Hipolito M, Longcore JE, Hyatt AD, Yabsley M, Martins AMCRPF, Mazzoni R, Davies AJ, Daszak P (2010) The North American bullfrog as a reservoir for the spread of Batrachochytrium dendrobatidis in Brazil. Animal Conservation 13:53-61

Schloegel LM, Toledo LF, Longcore JE, Greenspan SE, Vieira CA, Lee M, Zhao S, Wangen C, Ferreira CM, Hipolito M, Davies AJ, Cuomo CA, Daszak P, James TY (2012) Novel, panzootic and hybrid genotypes of amphibian chytridiomycosis associated with the bullfrog trade. Molecular Ecology 21:5162-5177

Sleeman J, Brand C, Wright S (2012) Strategies for wildlife disease surveillance. In: New Directions in Conservation Medicine, Aguirre A, Ostfeld R, Daszak P (editors), New York, Oxford University Press, pp 539-551 
Smith KF, Acevedo-Whitehouse K, Pedersen AB (2009) The role of infectious diseases in biological conservation. Animal Conservation 12:1-12

Solís R, Lobos G, Walker S, Fisher M, Bosch J (2010) Presence of Batrachochytrium dendrobatidis in feral populations of Xenopus laevis in Chile. Biological Invasions 12:1641-1646

Solís R, Penna M, De la Riva I, Fisher MC, Bosch J (2015) Presence of Batrachochytrium dendrobatidis in anurans from the Andes highlands of northern Chile. Herpetological Journal 24:55-59

Soto-Azat C, Valenzuela-Sánchez A, Clarke BT, Busse K, Ortiz JC, Barrientos C, Cunningham AA (2013a) Is chytridiomycosis driving Darwin's frogs to extinction? PLOS ONE 8:e79862

Soto-Azat C, Valenzuela-Sánchez A, Collen B, Rowcliffe MC, Veloso A, Cunningham AA (2013b) The population decline and extinction of Darwin's frogs. PLoS ONE 8:e66957

Soto-Azat C, Valenzuela-Sánchez A, Ortiz JC, Díaz-Páez H, Castro C, Charrier A, Correa C, Cuevas C, Lobos G, Mendez MA, Penna M, Peñafiel-Ricaurte A, Rabanal F, VélezR CM, Vidal MA, Angulo A (2015) ASG Chile leads update of the extinction risk of Chilean amphibians for the IUCN red list of threatened species. FrogLog 23:6-7

St-Amour V, Wong WM, Garner TWJ, Lesbarreres D (2008) Anthropogenic influence on prevalence of 2 amphibian pathogens. Emerging Infectious Diseases 14:11751176

Stöhr AC, Hoffmann A, Papp T, Robert N, Pruvost NBM, Reyer HU, Marschang RE (2013) Long-term study of an infection with ranaviruses in a group of edible frogs (Pelophylax kl. esculentus) and partial characterization of two viruses based on four genomic regions. Veterinary Journal 197:238-244

Stuart SN, Chanson JS, Cox NA, Young BE, Rodrigues ASL, Fischman DL, Waller RW (2004) Status and trends of amphibian declines and extinctions worldwide. Science 306:1783-1786

Tamura K, Stecher G, Peterson D, Filipski A, Kumar S (2013) MEGA6: Molecular Evolutionary Genetics Analysis version 6.0. Molecular Biology and Evolution 30:2725-2729

Teacher AGF, Cunningham AA, Garner TWJ (2010) Assessing the long-term impact of Ranavirus infection in wild common frog populations. Animal Conservation 13:514-522

Tinsley RC, Loumont C, KOBEL HR (1996) Geographical distribution and ecology. In: The biology of Xenopus, Tinsley RC, Kobel HR (editors), Oxford, Clarendon Press, pp 35-39

Une Y, Sakuma A, Matsueda H et al (2009) Ranavirus outbreak in North American bullfrogs (Rana catesbeiana), Japan. Emerging Infectious Diseases 15:1146-1147 
Veloso A, Formas R, Gerson H (2010) Calyptocephalella gayi. The IUCN Red List of Threatened Species 2010: e.T4055A10332590. Available: http://dx.doi.org/10.2305/IUCN.UK.2010-2.RLTS.T4055A10332590.en. [accessed January 11, 2016]

Voyles J, Young S, Berger L, Campbell C, Voyles WF, Dinudom A, Cook D, Webb R, Alford RA, Skerrat LF, Speare R (2009) Pathogenesis of amphibian chytridiomycosis, a cause of catastrophic amphibian declines. Science 326:582585

Warne RW, LaBumbard B, LaGrange S, Vredenburg VT, Catenazzi A (2016) Coinfection by chytrid fungus and ranaviruses in wild and harvested frogs in the tropical Andes. PLoS ONE 11:e0145864

Webb R, Berger L, Mendez D, Speare R (2005) MS-222 (tricaine methane sulfonate) does not kill the amphibian chytrid fungus Batrachochytrium dendrobatidis. Diseases of Aquatic Organisms 68:89-90

Zupanovic Z, Lopez G, Hyatt AD, Green B, Bartran G, Parkes H, Whittington RJ, Speare R (1998) Giant toads Bufo marinus in Australia and Venezuela have antibodies against 'ranaviruses'. Diseases of Aquatic Organisms 32:1-8

17 


\begin{tabular}{|l|l|l|l|l|l|l|l|l}
\hline Rinconada & $33^{\circ} 29^{\prime} 40^{\prime \prime}$; $70^{\circ} 49^{\prime} 47^{\prime \prime} \mathrm{W}$ & Lagoon & $\mathrm{XL}$ & 24 & 4 & $0.167 \pm 0.160$ & 10 & $0.417 \pm 0.213$ \\
\hline El Peral & $33^{\circ} 30^{\prime} 18^{\prime \prime} \mathrm{S} ; 71^{\circ} 36^{\prime} 13^{\prime \prime} \mathrm{W}$ & Lagoon & $\mathrm{XL}, \mathrm{PT}$ & $\begin{array}{l}81 \\
(79 \mathrm{XL}, 2 \mathrm{PT})\end{array}$ & 0 & 0 & $0.01 \pm 0.02$ \\
\hline Talagante & $33^{\circ} 41^{\prime} 05^{\prime \prime} \mathrm{S} ; 70^{\circ} 54^{\prime} 28^{\prime \prime} \mathrm{W}$ & $\begin{array}{l}\text { Agriculture } \\
\text { channels }\end{array}$ & $\mathrm{XL}, \mathrm{CG}$ & $\begin{array}{l}41 \\
(40 \mathrm{XL}, 1 \mathrm{CG})\end{array}$ & 4 & $0.098 \pm 0.095$ & 6 & $0.146 \pm 0.113$ \\
\hline San Guillermo & $33^{\circ} 50^{\prime} 56^{\prime \prime} \mathrm{S} ; 71^{\circ} 47^{\prime} 11^{\prime \prime} \mathrm{W}$ & Pond & $\mathrm{XL}$ & 8 & 0 & 0 & 2 & $0.250 \pm 0.387$ \\
\hline Talca & $35^{\circ} 26^{\prime} 45^{\prime \prime} \mathrm{S} ; 71^{\circ} 42^{\prime} 10^{\prime \prime} \mathrm{W}$ & Pond & $\mathrm{XL}$ & 24 & 0 & 0 & 0 & 0 \\
\hline Longaví & $35^{\circ} 55^{\prime} 57^{\prime \prime} \mathrm{S} ; 71^{\circ} 34^{\prime} 57^{\prime \prime} \mathrm{W}$ & Frog farm & CG & 8 & 0 & 0 & 8 & 1.000 \\
\hline Nahuelbuta & $37^{\circ} 49^{\prime} 46^{\prime \prime} \mathrm{S} ; 73^{\circ} 09^{\prime} 49^{\prime \prime} \mathrm{W}$ & River & TB & 1 & 0 & 0 & 0 & 0 \\
\hline
\end{tabular}

Table 1. Summary of Ranavirus (Rv) and Batrachochytrium dendrobatidis (Bd) prevalence by site between 2011 and 2013 in central Chile. Results of specific PCR assays from 187 amphibians of mixed species.

$\mathrm{XL}=$ Xenopus laevis, $\mathrm{PT}=$ Pleurodema thaul, $\mathrm{CG}=$ Calyptocephalella gayi, $\mathrm{TB}=$ Telmatobufo bullocki. 
Table 2. Summary of Ranavirus (Rv) and Batrachochytrium dendrobatidis (Bd) prevalence by host species between 2011 and 2013 in central Chile.

\begin{tabular}{|l|l|l|l|l|l|l|l|}
\hline \multicolumn{1}{|c|}{ Species } & $\mathbf{n}$ & $\mathbf{R v +}$ & $\begin{array}{c}\text { Prevalence of } \\
\text { infection } \mathbf{( \pm 9 5 \%} \mathbf{C l})\end{array}$ & $\mathbf{B d +}$ & $\begin{array}{c}\text { Prevalence of } \\
\text { infection } \mathbf{( \pm 9 5 \%} \mathbf{C l})\end{array}$ & $\begin{array}{c}\text { co- } \\
\text { infections }\end{array}$ & $\begin{array}{c}\text { Prevalence of } \\
\text { infection } \mathbf{( \pm 9 5 \%} \mathbf{C I})\end{array}$ \\
\hline Calyptocephalella gayi & 9 & $1^{\mathrm{a}}$ & $0.111 \pm 0.256$ & $8^{\mathrm{D}}$ & $0.889 \pm 0.256$ & 0 & 0 \\
\hline Pleurodema thaul & 2 & 0 & 0 & $1^{\mathrm{a}}$ & $0.500 \pm 6.353$ & 0 & 0 \\
\hline Telmatobufo bullocki & 1 & 0 & 0 & 0 & & 0 & 0 \\
\hline Xenopus laevis & 175 & $7^{\mathrm{c}}$ & $0.040 \pm 0.029$ & $18^{\mathrm{c}}$ & $0.103 \pm 0.046$ & $3^{\mathrm{c}}$ & $0.017 \pm 0.020$ \\
\hline TOTAL & 187 & 8 & $0.043 \pm 0.029$ & 27 & $0.144 \pm 0.051$ & 3 & $0.016 \pm 0.018$ \\
\hline
\end{tabular}

$\mathrm{a}=$ Dead in the wild.

$\mathrm{b}=$ Tissue obtained from aquaculture.

c=Euthanized after live capture. 
Figure 1. Map of central Chile showing locations of sites from which amphibians were sampled for Ranavirus and B. dendrobatidis (Bd) infection using PCR. The star indicates Santiago, the capital city of Chile. Each square indicates a site with Bdpositive animals. Each triangle indicates a site with Bd-positive and Ranaviruspositive animals. Each circle indicates a site where neither pathogen was detected. No site was positive for Ranavirus only. 1=Rinconada, 2=El Peral, 3=Talagante, 4=San Guillermo, 5=Talca, 6=Longaví, and 7=Nahuelbuta.

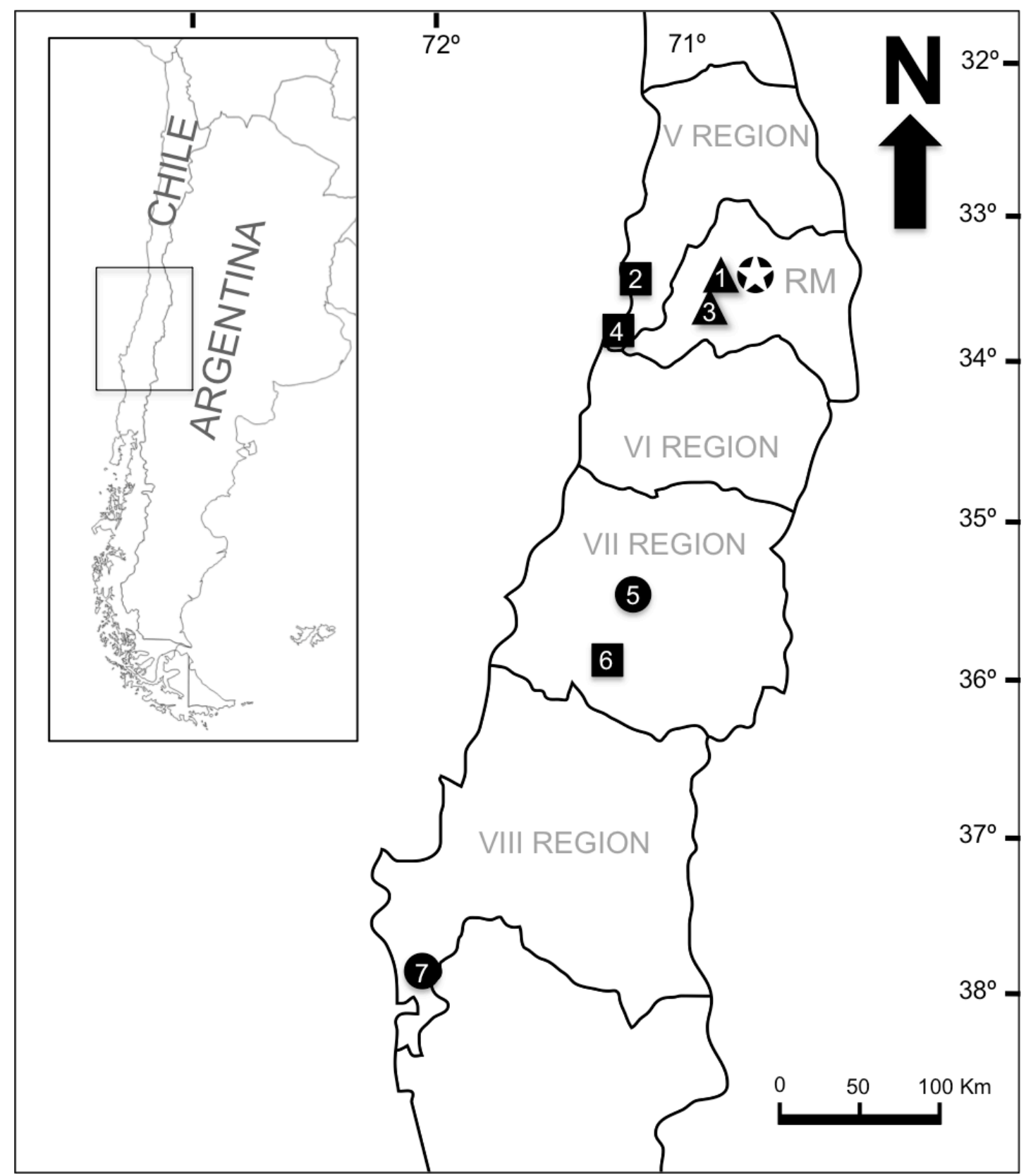

